\title{
Land Suitability Evaluation Using Fuzzy Continuous Classification (A Case Study: Ziaran Region)
}

\author{
Ali Keshavarzi (Corresponding author) \\ Department of Soil Science Engineering, University of Tehran \\ P.O.Box: 4111, Karaj 31587-77871, Iran
}

Tel: 98-261-223-1787 E-mail: aliagric@gmail.com, alikeshavarzi@ut.ac.ir

Fereydoon Sarmadian

Department of Soil Science Engineering, University of Tehran

P.O.Box: 4111, Karaj 31587-77871, Iran

Tel: 98-261-223-1787 E-mail: fsarmad@ut.ac.ir

Ahmad Heidari

Department of Soil Science Engineering, University of Tehran

P.O.Box: 4111, Karaj 31587-77871, Iran

Tel: 98-261-223-1787 E-mail: ahaidari@ut.ac.ir

Mahmoud Omid

Department of Agricultural Machinery Engineering, University of Tehran

P.O.Box: 4111, Karaj 31587-77871, Iran

Tel: 98-261-280-8138 E-mail: omid@ut.ac.ir

The research is financed by Department of Soil Science Engineering, University of Tehran

\begin{abstract}
Because conventional Boolean retrieval of soil survey data and logical models for assessing land suitability treat both spatial units and attribute value ranges as exactly specifiable quantities, they ignore the continuous nature of soil and landscape variation and uncertainties in measurement which can result in the misclassification of sites that just fail to match strictly defined requirements. The objective of this research is to apply fuzzy set theory for land suitability evaluation in Ziaran region in Qazvin province, Iran. The study area was divided into 15 land units and 9 land characteristics considered to be relevant to irrigated wheat. The weight contributions of individual characteristics to observed yield were determined using the analytic hierarchy process (AHP). The use of the fuzzy technique is helpful for land suitability evaluation and classification of continuous variation, especially in applications in which subtle differences in land characteristics are of a major interest.
\end{abstract}

Keywords: Fuzzy set, Continuous classification, AHP, Land index, Irrigated wheat, Ziaran

\section{Introduction}

Making effective decisions regarding agricultural land suitability problems are vital to achieve optimum land productivity and to ensure environmental sustainability (Kurtener et al., 2004). Land evaluation procedures focus increasingly on the use of quantitative procedures to enhance the qualitative interpretation of land resource surveys. Crucial to the estimation of land suitability is the matching of land characteristics with the requirements of envisaged land utilization types. Land evaluation results from a complex interaction of physical, chemical and bioclimatic processes and evaluation models are reliable enough to predict accurately the behaviour of land (Held et al., 2003; Ball and De la Rosa, 2006; Shahbazi et al., 2009).

Land evaluation is carried out to estimate the suitability of land for a specific use such as arable farming or irrigated agriculture. Land evaluation can be carried out on the basis of biophysical parameters and/or socio-economic conditions of an area (FAO, 1976). Biophysical factors tend to remain stable, whereas socio-economic factors that are affected by social, economic and political performances (Dent and Young, 1981; Triantafilis et al., 2001). Thus, physical land suitability evaluation is a prerequisite for land-use planning and 
development (Sys, 1985; Van Ranst et al., 1996). It provides information on the constraints and opportunities for the use of the land and therefore guides decisions on optimal utilization of land resources (FAO, 1984).

In 1976, FAO is provided a general framework for land suitability classification. In this framework, doesn't have been proposed a specific method for doing this classification. In later years, the collection of methods was presented based on the above framework (FAO, 1984). From the variation of these methods can be pointed maximum limitation and parametric methods. In parametric method, a quantitative classification is allocated to each characteristic of land. If a characteristic of land for a specific product was completely desired and provided optimum conditions for that, maximum degree 100 would belong to that characteristic and if it has limitation, the lower degree will be given to it. Later, allocated ranks will be used in calculation of the land index. In parametric method, different classes of land suitability are defined as completely separate and discrete groups and are separated from each other by distinguished and consistent range. Thus, land units that have moderate suitability can only choose one of the characteristics of predefined classes of land suitability. Fuzzy sets theory for the first time defined by Zadeh (1965) in order to quantitative defining and determining of some classes that are expressed vaguely such as "very important" and so on. In fuzzy thinking, determination of specific border is difficult and belonging of various elements to various concepts and issues are relative. In fuzzy theory, the membership was not two-valued, but it can allocate the range of numbers from zero to one. A function that expresses degree of membership is called membership function. In land evaluation with fuzzy method, mainly bell-shape functions, such as sigmoid, cauchy and kandel functions were used. Fuzzy model has been used by many researchers in land suitability evaluation (Tang et al., 1991; Van Ranst et al., 1996; Keshavarzi and Sarmadian, 2009). Most of the researchers, have been compared the results of this evaluation with other conventional methods such as maximum limitation, parametric and multiple regression methods in order to predicting the yield of production. Fritz and See (2005) studied the comparison of land cover maps using fuzzy agreement. The spatial fuzzy agreement between the two land cover products is provided. The results showed that fuzzy agreement can be used to improve the overall confidence in a land cover product. Sicat et al. (2005) used fuzzy modeling incorporating the farmers' knowledge to assign the weights of the membership functions. The final objective was to make land suitability maps for agriculture in Nizamabad district of Andhra Pradesh State in India. Tang et al. (1991) used fuzzy method for evaluation of Hamen lands in Liaoning province in China in order to cultivating corn. These researchers were obtained the final matrix of suitability with constituting weight matrix and land characteristics matrix and multiplication of them and finally were calculated the land index. In this study, they were used multiple regression to determination of weights. Tang et al. (1992) did the land suitability evaluation in the region of Aitayi in Liaoning province in China for dry maize using fuzzy, parametric and limitation methods and studied regression relationships between obtained suitability indices and the observed yield. The results of their investigation showed that indices obtained from fuzzy method had more correlation with the observed yield $(r=0.96)$. After fuzzy method, parametric method $(r=0.9)$ and finally limitation method had lowest correlation $(\mathrm{r}=0.8)$. They were used simulation method for selecting appropriate weights. Sanchez (2007) in his study for the investigation of land suitability for dry rice and rubber, used three methods including the investigation of land suitability using farmer's knowledge, land suitability classification with two-valued method using ALES model and evaluation based on fuzzy logic. He used AHP method for weighting in his study. The results of this study showed that obtained proportions from three methods had differences in some cases. Also integration of farmer's knowledge with evaluation methods increases the correlation of evaluations with region conditions. The selection of appropriate membership function for land evaluation depends on the degree of characteristics changes in transition zone and boundary of classes. After the selection of membership function, determination of transition zone's width is one of the most important and critical stages of decision in fuzzy sets theory and accuracy of results is indebted these decision.

Hence, the present study was carried out with objective to application of fuzzy continuous classification for evaluation of agricultural land suitability using Analytic Hierarchy Process in Ziaran region. Wheat yield information obtained from users (farmers) and policy makers (government officials) who are responsible for rural development.

\section{Materials and methods}

\subsection{Study area}

The land investigated in the research is located in Ziaran (Qazvin province in Iran) which has the area about

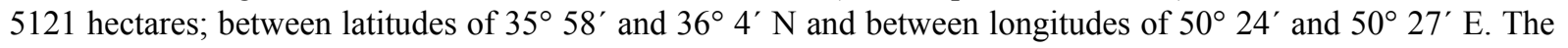
average, minimum and maximum heights points of Ziaran region are 1204, 1139 and 1269 meters from the sea level, respectively. Figure1 shows the study area in Iran. The soil moisture and temperature regimes of the region by means of Newhall software are Weak Aridic and Thermic, respectively. Based on soil taxonomy (USDA, 
2010), this region has soils in Entisols and Aridisols orders (Table 1).

\subsection{Data collection and soil sample analysis}

After preliminary studies of topographic maps (1:25000), using GPS, studying location was appointed. 70 soil samples were collected from different horizons of 15 soil profiles located in Ziaran region in Qazvin Province. Measured soil parameters included texture (determined using Bouyoucos hydrometer method), Organic Carbon (OC) was determined using Walkley-Black method (Nelson and Sommers, 1982). The Clod method (Blake and Hartge, 1986) was used to determine Bulk density (Bd). The moisture contents at field capacity and wilting point were determined with a pressure plate apparatus (Cassel and Nielsen, 1986) at -33 and $-1500 \mathrm{kPa}$, respectively. Water saturation percentage (SP) was determined using Gravimetry method, $\mathrm{CaCO}_{3}$ content was determined using Calcimetry method, gypsum content was determined using Acetone method and CEC (cation exchange capacity in $\mathrm{cmol}^{\mathrm{c}} \mathrm{kg}^{-1}$ soil) determined by the method of Bower (Sparks et al., 1996). pH, electrical conductivity (EC), dissolved $\mathrm{Ca}^{2+}, \mathrm{Mg}^{2+}, \mathrm{Na}^{+}$and $\mathrm{K}^{+}$were determined using standard methods (USDA, 1998).

\subsection{Fuzzy sets theory}

It is well known that many elements of land properties have uncertainties. Uncertainty is inherent in decision-making processes, which involve data and model uncertainty. These range from measurement errors, to inherent variability, to instability, to conceptual ambiguity or to simple ignorance of important factors. Fuzzy sets theory is a mathematical method used to characterize and propagate uncertainty and imprecision in data and functional relationships. Fuzzy sets are especially useful when insufficient data exist to characterize uncertainty using standard statistical measures (e.g., mean, standard deviation and distribution type). An underlying philosophy of the fuzzy sets theory is to provide a strict mathematical framework, where the imprecise conceptual phenomena in decision making may be precisely and rigorously studied, in particular for knowledge management (Kurtener et al., 2004). The fuzzy sets theory includes fuzzy mathematics, fuzzy measures, fuzzy integrals, etc. Fuzzy logic is a minor aspect of the whole field of fuzzy mathematics. In classical sets theory, the membership of a set is defined as true or false, 1 or 0 . Membership of a fuzzy set, however, is expressed on a continuous scale from 1 (full membership) to 0 (full non-membership).

Definition 1. Let $X$ be a set (universe). $D$ is called a fuzzy subset of $X$ if $D$ is a set of ordered pairs: $D=[(x, \mu$ $D(x)), x \in X]$, where $\mu D(x)$ is the grade of membership of $X$ in $D . \mu D(x)$ takes its values in the closed interval $[0,1]$. The closer $\mu D(x)$ is to 1 , the more $x$ belongs to $D$; the closer it is to 0 the less it belongs to $D$. If $[0,1]$ is replaced by the two element set $\{0,1\}$, then $D$ can be regarded as a subset of $X$ (Kurtener et al., 2004).

\subsection{Application of fuzzy set theory in land suitability evaluation}

The irrigated wheat requirements were determined using FAO framework for land evaluation (Sys, 1985). The studied area was divided into 15 land units and 9 land characteristics considered to be relevant to irrigated wheat. They included Slope (\%), Soil depth (cm), Climate (index), EC ( $\left.\mathrm{dSm}^{-1}\right)$, Exchangeable Sodium percentage (ESP), Volumetric content of gravel (\%), OC content in soil (\%), Soil texture (class) and Gypsum content (\%). (Table 2)

To determine the land suitability classes for irrigated wheat via land biophysical characteristics, fuzzy method was used. To determined degree of membership for each land characteristic and via square root method, land index in each land unit was obtained. Finally, land suitability classes were determined. In fuzzy method, based on irrigated wheat requirements, the sigmoid (Torbert et al., 2008 ) and Kandel (Sarmadian et al., 2009) membership functions were used to determine the degree of membership of each land characteristic to land suitability classes (Figures 2 and 3 ) and the results were put in a matrix R (called characteristic matrix).

Then, via Analytic Hierarchy Process (AHP) the weight of each effective land characteristic in irrigated wheat yield was calculated and put in weights matrix (W). The AHP is characterized by pairwise comparisons among decision elements for generation of relative matrix. In this method, pairwise comparisons are considered as inputs and relative weights are as outputs. The Saaty scale (2003) was used for generation of pairwise comparison matrix which relatively rates priorities for two criteria (Table 3). It was supposed that comparison matrix was reverse and reciprocal that means if a criterion $\mathrm{A}$ in comparison with criteria $\mathrm{B}$ has a double priority, it could be inferred that criteria B has a priority half of criteria A. The criteria priorities are defined according to expert's judgments. After generation of pairwise comparison matrix, the criteria weights are calculated that includes sum of each column of pairwise comparison matrix and division of each component by the result of each relevant column sum. The resulted matrix is knows as normalized pairwise comparison matrix. The average of each row of the pairwise comparison matrix is calculated and these average values indicate relative weights of compared criteria.

To determine the final land suitability class in each land unit, a multiple operator (combination) was used. The 
final matrix of land suitability (E) was calculated after multiplying the characteristic matrix $(\mathrm{R})$ in each land unit by weights matrix (W).

The components of $\mathrm{E}$ indicate the degree of membership of relevant land unit to land suitability classes. This matrix is calculated as below (Eq.1):

$E=W \circ R$

Where: ${ }^{\circ}$ is fuzzy operator created from Triangular norm $\mathrm{T}$ (as minimum) and Triangular conorm $\mathrm{T}^{*}$ (as maximum) (Ruan, 1990) (Table 4).

According to these norms, the best result for final land suitability matrix is achieved via formula presented as below (Keshavarzi and Sarmadian, 2009):

$$
\begin{aligned}
& e_{j}=\min \left(a_{1}+a_{2}+\ldots+a_{n}, 1\right) \\
& a_{i}=\max \left(0, w_{i}+r_{i j}-1\right), \quad i=1,2, \ldots, n
\end{aligned}
$$

Where:

r: components of characteristic matrix $(R)$ for land characteristic of $i$ under the land suitability class of $j$

w: components of weights matrix (W) for land characteristic of $i$

e: components of final land suitability matrix (E) for land suitability classes of $\mathrm{S}_{1}$ to $\mathrm{N}$

The final land suitability matrix for land unit $10\left(\mathrm{E}_{10}\right)$ is shown as an example in below:

$$
\begin{aligned}
& \begin{array}{llll}
\mathrm{S}_{1} & \mathrm{~S}_{2} & \mathrm{~S}_{3} & \mathrm{~N}
\end{array} \\
& \mathrm{E}_{10}=\left[\begin{array}{llll}
0.74 & 0.23 & 0.09 & 0
\end{array}\right]
\end{aligned}
$$

In order to calculate land index, the sum of components of land suitability matrix (E) is set to one (standardized) and the new components of matrix are multiplied by average of indices of land suitability classes, respectively, based on the following formula (Sarmadian et al., 2009):

$L I=\sum\left[d\left(E_{j}\right) \times A_{j}\right]$

Where:

LI: land index

d: normalized (standardized) value of land suitability matrix (E)

A: average of maximum and minimum indices of land suitability classes

\section{Results and discussion}

Pairwise comparison matrix and normalized pairwise comparison matrix with criteria weights are shown in Tables 5 and 6, respectively. Due to higher weight, gravel volume percentile in soil was the most significant characteristic (criteria). The soil depth was the least significant criteria among all effective criteria in irrigated wheat yield. By the determined land characteristic weights, the weight matrix (W) was generated as the matrix below:

$$
\mathrm{W}=\left[\begin{array}{lllllllll}
0.239 & 0.024 & 0.044 & 0.154 & 0.213 & 0.129 & 0.086 & 0.066 & 0.045
\end{array}\right]
$$

The weight matrix (W) multiplied by characteristic matrix (R) for each land unit based on fuzzy operator (combination) and resulted in the final land suitability matrix (E). Then, land indices were calculated based on final E matrix in each land unit. Table 7, shows the observed irrigated wheat yield, land suitability classes and land indices obtained by fuzzy method for different land units in Ziaran region. According to table 7, maximum and minimum observed yield were 5.30 and 0.00 (Ton.ha ${ }^{-1}$ ) respectively. In land unit 9, due to high EC (43.9 $\mathrm{dSm}^{-1}$ ) and ESP (42.3\%), the irrigated wheat yield is near to zero. The calculated regression between land index and observed irrigated wheat yield (Figure 4) were 0.91 for fuzzy method.

Major limitations to wheat yield were gravel and organic carbon. Emphasis should be placed on soil management techniques that conserve organic matter and enhance nutrient and water-holding capacity of the soil. A comparison between results of this research and other investigators (Tang et al., 1991; Tang et al., 1992; Van Ranst et al., 1996; Sanchez, 2007 ; Joss et al., 2008; Keshavarzi and Sarmadian, 2009) indicated that the fuzzy method with higher correlation factor, had more accuracy and capability of predicting yield, since fuzzy set method considered the continual land changes and is more efficient in reflecting spatial variability of soil characteristic rather than Boolean's two-valued logic that overlooks a considerable section of useful information 
during land evaluation processing. Nonetheless, the accuracy of the results is mainly dependant on the designated weights to different land characteristics. Although in land suitability evaluation, nowadays the emphasis is on quantitative (numerical) methods, because the fuzzy sets theory's problem in land suitability evaluation needs a high volume of calculations. On the other hand, increasing the number of land characteristic increases the number of pairwise comparisons and decision making on spatial variability of different characteristics in each land unit becomes difficult, because different characteristics has different weights and designation of weight to characteristics needs more experience and criteria precedence. The weakest part of the fuzzy set methodology for land evaluation is the way in which membership functions, class centers, cross-over values and weight values are chosen (Burrough, 1989; Keshavarzi and Sarmadian, 2009). Davidson et al. (1994) also stated that one critical issue in the application of fuzzy set theory to land suitability assessment is the choice of membership functions. This is not a straightforward task since decisions have to be made on membership values according to degree of suitability. The problem of how to define the parameters of the fuzzy membership functions is more complicated than the Boolean equivalent because it requires not only specifications of what kind of membership function and class boundary values, but also the widths of the transition zones. Another critical issue is the choice of weights which clearly have a major impact on results. Some guidance can be obtained from the literature and expert experience on land properties relevant to particular crops, but ultimately subjective decisions have to be made. The strength of the fuzzy set approach in land evaluation is that it starts from the promise that nature may be inherently vague or imprecise, and does not try to pretend that the real world, which has been modeled by data entitles created by human or machine observation, is more exact, or more perfect than it really is (Burrough, 1989).

\section{Conclusion}

Fuzzy logic is an attempt to extend the concept of continuous variation of soil properties from the geographic space to the attribute space (Burrough et al., 1997). The use of fuzzy technique in this study produced land suitability for irrigated wheat in a continuous scale. Land suitability indices reflect inherent fertility of the soils (Braimoh et al., 2004). The approach in this research is well applicable for applications in which subtle differences in land characteristic is of the major interests. Usage of SI model permits the evaluation of the land characteristics limitations to wheat in the study area. Considering major constraints to the use of fuzzy technique for land suitability evaluation, it results valuable information for identifying major limitations to crops production and strategies for overcoming them. The most important factor that complicates a decision making problem, is domination of uncertainty situation. Decision making under uncertainty situation is complex and difficult, thus achieving a suitable and optimum choice demands compliance with rules, values and different description aspects of decision process. Fuzzy set theory can continually show land continuity in different land classes and this one is of its advantages. The other advantage is that it allows the environment to be inherently vague and does not try to limit soil continual system to the data measured by soil science researchers (Burrough et al., 1992).

\section{References}

Ball, A., \& De la Rosa, D. (2006). Modelling possibilities for the assessment of soil systems. In N. Uphoff, A. Ball, E. Fernandes, H. Herren, O. Husson, M. Laing, Ch. Palm, J. Pretty, P. Sanchez, N. Sanginga, J. Thies (Eds.), Biological Approaches to Sustainable Soil Systems. CRC Press, BocaRaton, FL, USA.

Blake, G. R., \& Hartge, K. H. (1986). Particle density. In A. Klute (Eds.), Methods of soil analysis. Part 1. Agron. Monogr. 9. ASA, Madison, WI. pp. 377-382.

Braimoh, A. K., \& Stein, A. (2004). Land evaluation for Maize based on Fuzzy set and interpolation. Journal of Environmental Management, 33(2), 226-238.

Burrough, P. A. (1989). Fuzzy mathematical methods for soil survey and land evaluation. Journal of Soil Science, 40, 477-492.

Burrough, P. A., MacMillan, R. A., \& Van Denrsen, W. (1992). Fuzzy classification methods for determining land suitability from soil profile observations and topography. Journal of Soil Science, 43, 193-210.

Burrough, P. A., Van Gaans, P. F. M., \& Hootsmans, R. (1997). Continuous classification in soil survey: spatial correlation, confusion and boundaries. Geoderma, 77, 115-135.

Cassel, D. K., \& Nielsen, D. R. (1986). Field capacity and available water capacity. In A. Klute, (Eds.), Methods of Soil Analysis. Part 1, second ed. Agron. Monogr. 9. ASA and SSSA, Madison, WI, pp. 901-926.

Davidson, D. A., Theocharopoulos, S. P., \& Bloksma, R. J. (1994). A land evaluation project in Greece using GIS and based on Boolean and fuzzy set methodologies. International Journal of Geographic Information 
Systems, 8(4), 369-384.

Dent, D., \& Young, A. (1981). Soil survey and land evaluation. George Allen and Uniwin: Boston.

FAO. (1976). A framework for land evaluation. FAO Soils Bulletin 32, Rome.

FAO. (1984). Guidelines: Land evaluation for rainfed agriculture. FAO Soils Bulletin 52, Rome.

Fritz, S., \& See, L. (2005). Comparison of land cover maps using fuzzy agreement. International Journal of Geographical Information Science, 19(7), 787-807.

Held, M., Imeson, A., \& Montanarella, L. (2003). Economic Interests and Benefits of Sustainable Use of Soils and Land Management. Joint Res. Centre Press, Ispra, Italy.

Joss, B. N., Hall, R. J., Sidders, D. M., \& Keddy, T. J. 2008. Fuzzy-logic modeling of land suitability for hybrid poplar across the Prairie Provinces of Canada. Earth and Environmental Science, 141, 79-96.

Keshavarzi, A., \& Sarmadian, F. (2009). Investigation of fuzzy set theory`s efficiency in land suitability assessment for irrigated wheat in Qazvin province using Analytic hierarchy process (AHP) and multivariate regression methods. Proc. 'Pedometrics 2009' Conf, August 26-28, Beijing, China.

Kurtener, D., Krueger-Shvetsova, E., \& Dubitskaia, I. (2004). Quality estimation of data collection. In UDMS, UDMS Press, Giorggia-Venice. pp. 9101-9109.

Nelson, D.W., \& Sommers, L. E. (1982). Total carbon, organic carbon, and organic matter. In A. L. Page, R. H. Miller, \& D.R. Keeney (Eds.), Methods of Soil Analysis. Part II, 2nd ed. American Society of Agronomy, Madison, WI, USA. pp. 539-580.

Ruan, D. (1990). A critical study of widely used fuzzy implication operators and their influence on the inference rules in fuzzy expert systems. Doctoral Thesis, State University of Gent, Belgium. 155 pp.

Saaty, T. L. (2003). Decision-making with the AHP: Why is the principal eigenvector necessary? European Journal of Operational Research, 145, 85-91.

Sanchez, J. F. (2007). Applicability of knowledge-based and Fuzzy theory-oriented approaches to land suitability for upland rice and rubber. M.Sc. Thesis, ITC, the Netherland.

Sarmadian, F., Keshavarzi, A., Rajabpour, B., \& Rajabpour, A. (2009). Multi-Criteria Decision Making in Fuzzy Modeling of Land Suitability Evaluation (Case Study: Takestan area of central Iran). Proc. 'Pedometrics 2009' Conf, August 26-28, Beijing, China.

Shahbazi, F., Jafarzadeh, A. A., Sarmadian, F., Neyshaboury, M. R., Oustan, S., Anaya-Romero, M., Lojo, M., \& De la Rosa D. (2009). Climate change impact on land capability using MicroLEIS DSS. Int. Agrophysics, 23, 277-286.

Sicat, R. S., Carranza, E. J. M., \& Nidumolu, U. B. (2005). Fuzzy modeling of farmers' knowledge for land suitability classification. Agricultural systems, 83, 49-75.

Sparks, D. L., Page, A. L., Helmke, P. A., Leoppert, R. H., Soltanpour, P. N., Tabatabai, M. A., Johnston, G. T., \& Summer, M. E. (1996). Methods of soil analysis. Soil Sci. Soc. of Am. Madison, Wisconsin.

Sys, С. (1985). Land evaluation, part I, И, Ш . ITC, University of Ghent, Belgium, 343 pp.

Tang, H., Debaveye, J., Ruan, D., \& Van Ranst, E. (1991). Land suitability classification based on fuzzy set theory. Pedologie, 3, 277-290.

Tang, H., Van Ranst, E., \& SYS, C. (1992). An approach to predict land production potential for irrigated and rainfed winter wheat in Pinan County, China. Soil Technology, 5, 213-224.

Torbert, H. A., Krueger, E., \& Kurtener, D. (2008). Soil quality assessment using fuzzy modeling. Int. Agrophysics, 22, 365-370.

Triantafilis, J., Ward, W. T., \& McBratney, A. B. (2001). Land suitability assessment in the Namoi Valley of Australia, using a continuous model. Amsterdam Journal of Soil Research, 39, 273-290.

USDA. (1998). Field book for describing and sampling soils. Version 1.1, Lincoln: Nebraska. NRCS.

USDA. (2010). Soil Survey Staff. Keys to Soil Taxonomy. 11 th edition.

Van Ranst, E., Tang, H., Groenemans, R., \& Sinthurahat, S. (1996). Application of Fuzzy logic to land suitability for rubber production in Peninsular Thailand. Geoderma, 70, 1-19.

Zadeh L. A. (1965). Fuzzy sets. Information and control, 8, 338-353. 
Table 1. Soil classification in the study area based on soil taxonomy (2010)

\begin{tabular}{|c|c|}
\hline $\begin{array}{c}\text { Soil } \\
\text { mapping } \\
\text { unit }\end{array}$ & Soil classification \\
\hline 1 & Fine-loamy, mixed, super active, thermic, Xeric Haplocambids \\
\hline 2 & Coarse-loamy over fragmental, mixed, super active, calcareous, shallow, thermic, Xeric Torrifluvents \\
\hline 3 & Coarse-loamy, mixed, super active, thermic, Xeric Torrifluvents \\
\hline 4 & Coarse-loamy, mixed, super active, thermic, Xerofluventic Haplocambids \\
\hline 5 & Sandy-skeletal over coarse loamy, mixed, super active, calcareous, thermic, Xeric Torrifluvents \\
\hline 6 & Fine, mixed, semi active, thermic, Xeric Haplocalcids \\
\hline 7 & Fine-loamy, mixed, active, thermic, Xeric Haplocalcids \\
\hline 8 & Fine-loamy over clayey, mixed, active, thermic, Sodic xeric Haplocambids \\
\hline 9 & Fine-loamy, mixed, super active, thermic, Gypsic Aquisalids \\
\hline 10 & Fine-loamy, mixed, super active, thermic, Typic Haplogypsids \\
\hline 11 & Fine, mixed, active, thermic, Xeric Haplocalcids \\
\hline 12 & Fine-loamy, mixed, super active, thermic, Xeric Haplocalcids \\
\hline 13 & Fine, mixed, active, thermic, Xeric Haplocalcids \\
\hline 14 & Fine-loamy, mixed, super active, thermic, Xeric Haplocalcids \\
\hline 15 & Coarse- loamy over fragmental, mixed, super active, calcareous, shallow, thermic, Xeric Torriorthents \\
\hline
\end{tabular}

Table 2. Selected land characteristics in Ziaran region

\begin{tabular}{|c|c|c|c|c|c|c|c|c|c|}
\hline \multirow[b]{2}{*}{$\begin{array}{l}\text { Land } \\
\text { Unit }\end{array}$} & \multicolumn{9}{|c|}{ Land Characteristics } \\
\hline & $\begin{array}{l}\text { Slope } \\
(\%)\end{array}$ & ESP & $\begin{array}{l}\mathrm{OC} \\
(\%)\end{array}$ & $\begin{array}{c}\mathrm{EC} \\
\left(\mathrm{dSm}^{-1}\right)\end{array}$ & $\begin{array}{c}\text { Gypsum } \\
(\%)\end{array}$ & $\begin{array}{l}\text { Soil texture } \\
\text { (class) }^{*}\end{array}$ & $\begin{array}{l}\text { Climate } \\
\text { (index) }\end{array}$ & $\begin{array}{c}\text { Gravel } \\
(\%)\end{array}$ & $\begin{array}{l}\text { Soil depth } \\
\text { (cm) }\end{array}$ \\
\hline 1 & 1.50 & 1.53 & 0.37 & 1.18 & 0.00 & C.L & 92.30 & 5.88 & 170 \\
\hline 2 & 2.50 & 1.42 & 0.61 & 1.16 & 0.00 & S.L & 92.30 & 25.63 & 50 \\
\hline 3 & 1.50 & 1.19 & 0.61 & 0.94 & 0.00 & $\mathrm{~L}$ & 92.30 & 0.00 & 200 \\
\hline 4 & 1.50 & 9.18 & 0.76 & 1.40 & 0.00 & $\mathrm{~L}$ & 92.30 & 1.88 & 175 \\
\hline 5 & 1.50 & 2.34 & 1.04 & 1.20 & 0.00 & S.L & 92.30 & 23.38 & 170 \\
\hline 6 & 0.75 & 7.49 & 0.75 & 2.35 & 0.00 & $\mathrm{C}$ & 92.30 & 0.00 & 170 \\
\hline 7 & 0.75 & 9.10 & 0.94 & 3.47 & 0.00 & $\mathrm{~L}$ & 92.30 & 0.10 & 180 \\
\hline 8 & 1.50 & 23.50 & 0.75 & 6.03 & 0.00 & C.L & 92.30 & 0.00 & 180 \\
\hline 9 & 0.75 & 42.30 & 0.66 & 43.90 & 4.97 & S.C.L & 92.30 & 0.00 & 120 \\
\hline 10 & 4.00 & 1.95 & 0.67 & 2.00 & 9.37 & S.C.L & 92.30 & 0.00 & 170 \\
\hline 11 & 1.50 & 9.09 & 0.47 & 2.34 & 0.00 & $\mathrm{C}$ & 92.30 & 0.00 & 190 \\
\hline 12 & 0.75 & 7.05 & 0.56 & 1.67 & 0.00 & S.C.L & 92.30 & 0.70 & 170 \\
\hline 13 & 1.50 & 1.83 & 0.38 & 1.06 & 0.00 & C.L & 92.30 & 1.39 & 160 \\
\hline 14 & 1.50 & 8.98 & 0.57 & 1.92 & 0.00 & S.L & 92.30 & 1.04 & 180 \\
\hline 15 & 2.50 & 1.14 & 0.76 & 0.96 & 0.00 & $\mathrm{~L}$ & 92.30 & 14.05 & 40 \\
\hline
\end{tabular}

$* \mathrm{C}=$ Clay, $\mathrm{L}=$ Loam, C.L $=$ Clay Loam, $\mathrm{S} . \mathrm{L}=$ Sandy Loam, S.C.L= Sandy Clay Loam 
Table 3. The Saaty scale (2003) was used for generation of pairwise comparison matrix

\begin{tabular}{|c|c|}
\hline Intensity of importance & Definition \\
\hline 1 & Equal importance \\
\hline 2 & Equal to moderate importance \\
\hline 3 & Moderate to strong importance \\
\hline 4 & Strong importance \\
\hline 5 & Strong to very strong importance \\
\hline 6 & Very strong importance \\
\hline 7 & Very to extremely strong \\
\hline 8 & Extreme importance \\
\hline 9 &
\end{tabular}

Table 4. Examples of triangular norm $\mathrm{T}$ and triangular conorm $\mathrm{T}^{*}$ (Ruan, 1990)

\begin{tabular}{|c|c|}
\hline Triangular norm $\mathrm{T}$ & Triangular conorm $\mathrm{T}^{*}$ \\
\hline Minimum & Maximum \\
$\mathrm{T}(\mathrm{a}, \mathrm{b})=\min (\mathrm{a}, \mathrm{b})$ & $\mathrm{T}^{*}(\mathrm{a}, \mathrm{b})=\max (\mathrm{a}, \mathrm{b})$ \\
\hline Product & Probabilistic sum \\
$\mathrm{T}(\mathrm{a}, \mathrm{b})=\mathrm{a} . \mathrm{b}$ & $\mathrm{T}^{*}(\mathrm{a}, \mathrm{b})=\mathrm{a}+\mathrm{b}-\mathrm{a} \cdot \mathrm{b}$ \\
\hline Bounded product & Bounded sum \\
$\mathrm{T}(\mathrm{a}, \mathrm{b})=\max (0, \mathrm{a}+\mathrm{b}-1)$ & $\mathrm{T}^{*}(\mathrm{a}, \mathrm{b})=\min (\mathrm{a}+\mathrm{b}, 1)$ \\
\hline
\end{tabular}

Table 5. Pairwise comparison matrix

\begin{tabular}{|c|c|c|c|c|c|c|c|c|c|}
\hline Criteria & $\begin{array}{c}\text { Gravel } \\
(\%)\end{array}$ & $\begin{array}{l}\text { Soil depth } \\
\text { (cm) }\end{array}$ & $\begin{array}{c}\text { Gypsum } \\
(\%)\end{array}$ & $\begin{array}{l}\text { Texture } \\
\text { (class) }\end{array}$ & $\begin{array}{l}\mathrm{OC} \\
(\%)\end{array}$ & $\begin{array}{c}\mathrm{EC} \\
\left(\mathrm{dSm}^{-1}\right)\end{array}$ & ESP & $\begin{array}{c}\text { Slope } \\
(\%)\end{array}$ & $\begin{array}{l}\text { Climate } \\
\text { (index) }\end{array}$ \\
\hline Gravel (\%) & 1.00 & 6.00 & 5.00 & 2.00 & 2.00 & 3.00 & 3.00 & 4.00 & 3.00 \\
\hline Soil depth $(\mathrm{cm})$ & 0.17 & 1.00 & 0.33 & 0.20 & 0.16 & 0.20 & 0.25 & 0.16 & 0.50 \\
\hline Gypsum (\%) & 0.20 & 3.00 & 1.00 & 0.25 & 0.16 & 0.20 & 0.25 & 0.50 & 2.00 \\
\hline Texture (class) & 0.50 & 5.00 & 4.00 & 1.00 & 0.33 & 2.00 & 3.00 & 4.00 & 3.00 \\
\hline $\mathrm{OC}(\%)$ & 0.50 & 6.00 & 6.00 & 3.00 & 1.00 & 2.00 & 3.00 & 5.00 & 3.00 \\
\hline $\mathrm{EC}(\mathrm{dSm})$ & 0.33 & 5.00 & 5.00 & 0.50 & 0.50 & 1.00 & 2.00 & 3.00 & 4.00 \\
\hline ESP & 0.33 & 4.00 & 4.00 & 0.33 & 0.33 & 0.50 & 1.00 & 2.00 & 2.00 \\
\hline Slope (\%) & 0.25 & 6.00 & 2.00 & 0.25 & 0.20 & 0.33 & 0.50 & 1.00 & 2.00 \\
\hline Climate (index) & 0.33 & 2.00 & 0.50 & 0.33 & 0.33 & 0.25 & 0.50 & 0.50 & 1.00 \\
\hline
\end{tabular}


Table 6. Normalized pairwise comparison matrix with criteria weights

\begin{tabular}{|l|c|c|c|c|c|c|c|c|c|c|}
\hline \multicolumn{1}{|c|}{ Criteria } & $\begin{array}{c}\text { Gravel } \\
(\%)\end{array}$ & $\begin{array}{c}\text { Soil depth } \\
(\mathrm{cm})\end{array}$ & $\begin{array}{c}\text { Gypsum } \\
(\%)\end{array}$ & $\begin{array}{c}\text { Texture } \\
(\text { class })\end{array}$ & $\begin{array}{c}\text { OC } \\
(\%)\end{array}$ & $\begin{array}{c}\text { EC } \\
\left(\mathrm{dSm}^{-1}\right)\end{array}$ & ESP & $\begin{array}{c}\text { Slope } \\
(\%)\end{array}$ & $\begin{array}{c}\text { Climate } \\
(\text { index })\end{array}$ & Weight \\
\hline Gravel (\%) & 0.276 & 0.158 & 0.180 & 0.254 & 0.397 & 0.316 & 0.222 & 0.198 & 0.146 & $\mathbf{0 . 2 3 9}$ \\
\hline Soil depth (cm) & 0.046 & 0.026 & 0.012 & 0.025 & 0.033 & 0.021 & 0.019 & 0.008 & 0.024 & $\mathbf{0 . 0 2 4}$ \\
\hline Gypsum (\%) & 0.055 & 0.079 & 0.036 & 0.032 & 0.033 & 0.021 & 0.019 & 0.025 & 0.098 & $\mathbf{0 . 0 4 4}$ \\
\hline Texture (class) & 0.138 & 0.132 & 0.144 & 0.127 & 0.066 & 0.211 & 0.222 & 0.198 & 0.146 & $\mathbf{0 . 1 5 4}$ \\
\hline OC (\%) & 0.138 & 0.158 & 0.216 & 0.381 & 0.199 & 0.211 & 0.222 & 0.248 & 0.146 & $\mathbf{0 . 2 1 3}$ \\
\hline EC (dSm ) & 0.092 & 0.132 & 0.180 & 0.064 & 0.099 & 0.105 & 0.148 & 0.149 & 0.195 & $\mathbf{0 . 1 2 9}$ \\
\hline ESP & 0.092 & 0.105 & 0.144 & 0.042 & 0.066 & 0.053 & 0.074 & 0.099 & 0.098 & $\mathbf{0 . 0 8 6}$ \\
\hline Slope (\%) & 0.069 & 0.158 & 0.072 & 0.032 & 0.040 & 0.035 & 0.037 & 0.050 & 0.098 & $\mathbf{0 . 0 6 6}$ \\
\hline Climate (index) & 0.092 & 0.053 & 0.018 & 0.042 & 0.066 & 0.026 & 0.037 & 0.025 & 0.049 & $\mathbf{0 . 0 4 5}$ \\
\hline
\end{tabular}

Table 7. Observed irrigated wheat yield, land suitability classes and land indices obtained by fuzzy approach for different land units in Ziaran region

\begin{tabular}{|c|c|c|}
\hline \multirow{2}{*}{$\begin{array}{c}\text { Land unit } \\
\text { No. }\end{array}$} & $\begin{array}{c}\text { Observed yield } \\
\text { (Ton/ha) }\end{array}$ & $\begin{array}{c}\text { Land suitability classes evaluation } \\
\text { for irrigated wheat }\end{array}$ \\
\cline { 3 - 3 } & & $\begin{array}{c}\text { Fuzzy approach } \\
\text { (index) }\end{array}$ \\
\hline 1 & 4.20 & $\mathrm{~S}_{1}(76.23)$ \\
\hline 2 & 3.10 & $\mathrm{~S}_{2}(70.36)$ \\
\hline 3 & 4.80 & $\mathrm{~S}_{1}(85.70)$ \\
\hline 4 & 4.50 & $\mathrm{~S}_{1}(83.14)$ \\
\hline 5 & 3.60 & $\mathrm{~S}_{1}(76.55)$ \\
\hline 6 & 5.30 & $\mathrm{~S}_{1}(89.65)$ \\
\hline 7 & 4.80 & $\mathrm{~S}_{1}(88.43)$ \\
\hline 8 & 4.30 & $\mathrm{~S}_{1}(80.36)$ \\
\hline 9 & 0.00 & $\mathrm{~N}_{(17.20)}$ \\
\hline 10 & 5.20 & $\mathrm{~S}_{2}(74.60)$ \\
\hline 11 & 4.50 & $\mathrm{~S}_{1}(81.50)$ \\
\hline 12 & 5.00 & $\mathrm{~S}_{1}(82.14)$ \\
\hline 13 & 4.80 & $\mathrm{~S}_{1}(84.60)$ \\
\hline 14 & 4.30 & $\mathrm{~S}_{1}(79.08)$ \\
\hline 15 & 3.30 & $\mathrm{~S}_{2}(74.30)$ \\
\hline
\end{tabular}




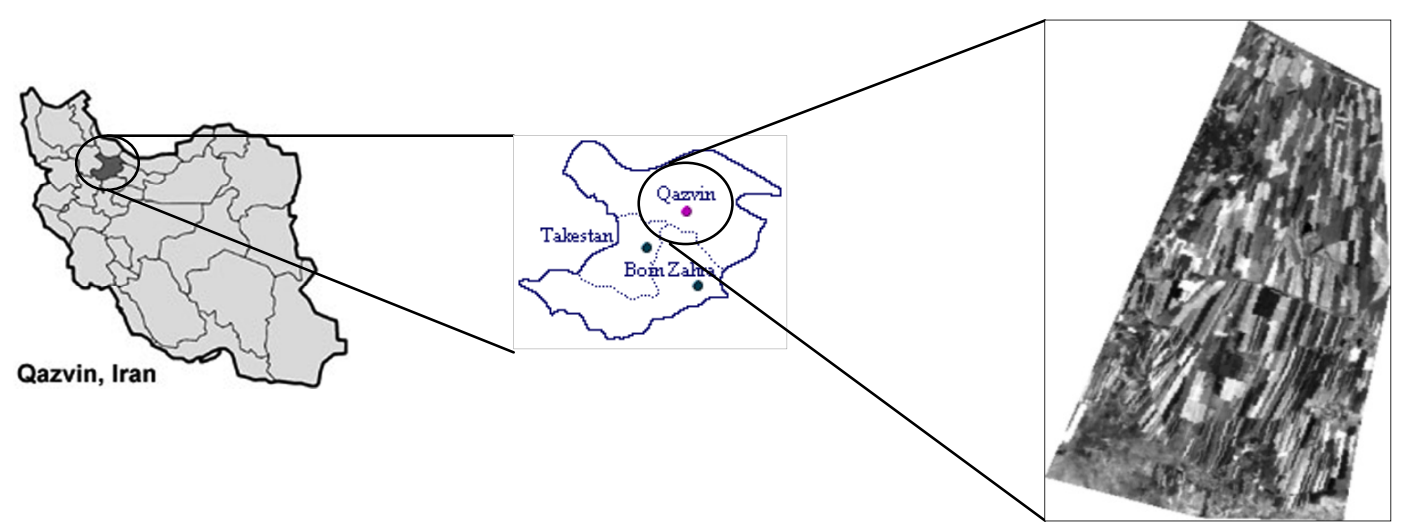

Figure 1. Location of the study area

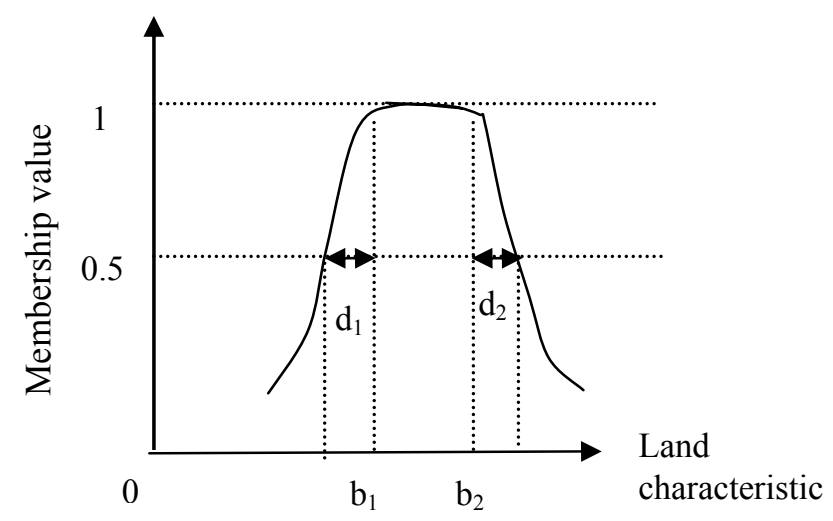

$$
M F_{X}= \begin{cases}1 /\left[1+\left(\frac{\left(x-b_{1}\right)}{d}\right)^{2}\right] & x<b_{1} \\ 1 /\left[1+\left(\frac{x-b_{2}}{d}\right)^{2}\right] & x>b_{2}\end{cases}
$$

Figure 2. Kandel membership function and its equation $\left(b_{1}\right.$ and $b_{2}$ are the lower limit and upper limits, respectively, and $d_{1}$ and $d_{2}$ are transitional zone widths)

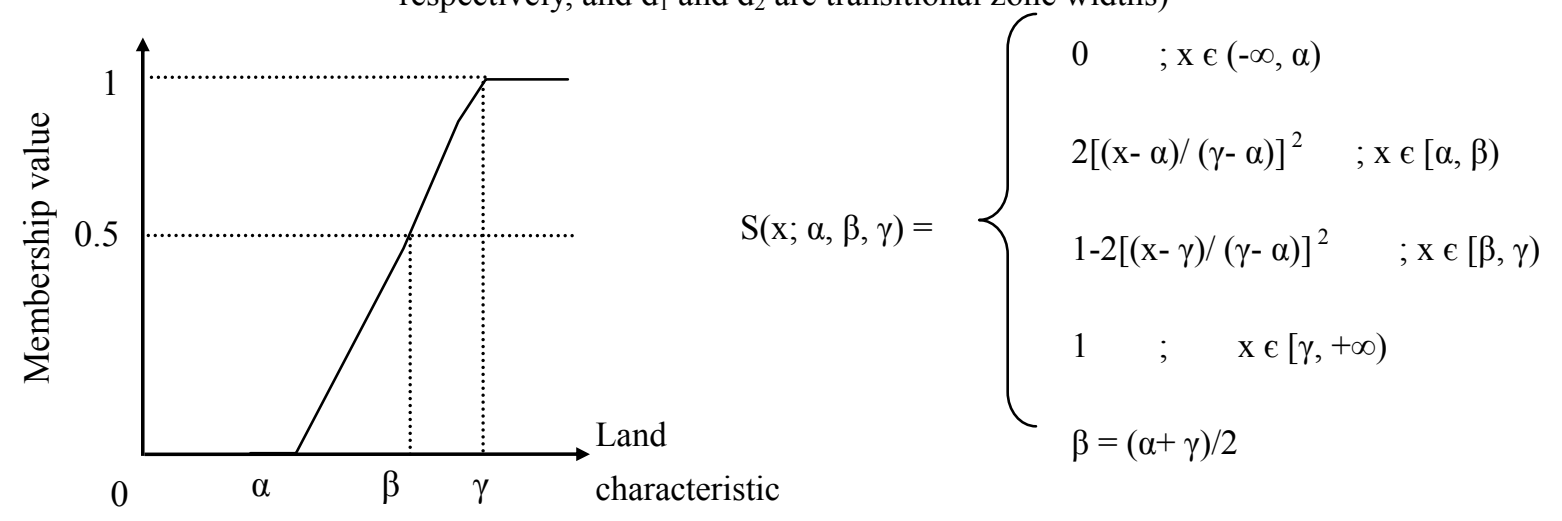

Figure 3. Sigmoid membership function and its equation

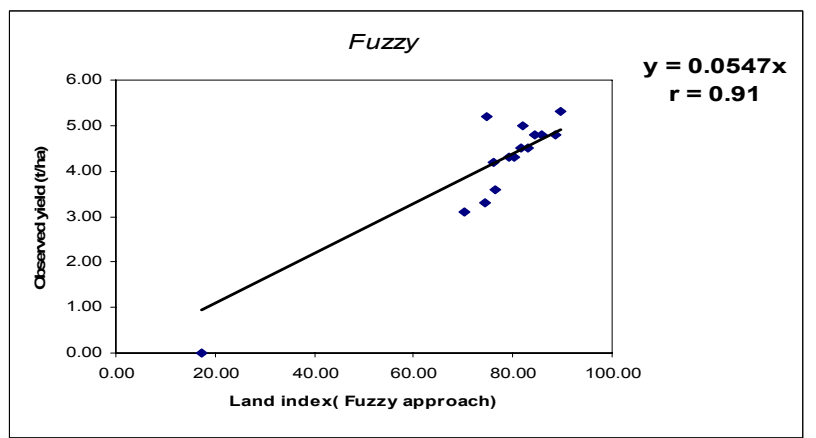

Figure 4. Linear regression between land suitability index and observed irrigated wheat yield in fuzzy approach in Ziaran region 